\title{
FACTORS AFFECTING SENSITIVITY OF COMMERCIAL BANKS TO BANK RUN IN THE VISEGRAD COUNTRIES
}

\author{
Pavla Klepková Vodová, Daniel Stavárek
}

\section{Introduction}

The recent financial crisis has shown that liquidity risk plays an important role in the contemporary financial system. This is especially true for economies that are traditionally based on banks and credit markets. A liquidity shock may propagate through a real channel or an information channel and then affect the entire financial system (Frait \& Komárková, 2011). As a systemic banking crisis can have costly consequences such as declines in gross domestic product growth, real house prices and real equity prices and increases in unemployment rate, real public debt, among other effects (Reinhart and Rogoff, 2009), it is not surprising that most regulators, policymakers and academics devote significant attention to various aspects of liquidity risk measurement and management. National regulators monitor the level of bank liquidity in individual banking sectors. New legislative rules concerning bank liquidity were issued in December 2010. One component of the Basel III rules strengthens liquidity risk regulation by imposing minimum liquidity standards (Liquidity Coverage Ratio and Net Stable Funding Ratio) and implementing monitoring tools to assess liquidity risk (BIS, 2010).

There are also numerous empirical studies focusing on the risk of contagion through the interbank market (e.g., Allen \& Gale, 2000; Blavarg \& Nimander, 2002; Memmel \& Sachs, 2013; or Wells, 2004), on the determinants of bank liquidity risk (such as Aspachs et al., 2005; Bunda \& Desquilbet, 2008; Dinger, 2009; Lucchetta, 2007; Moore, 2010; or Rauch et al., 2010) or on the sensitivity of banks to various liquidity shocks (e.g., Boss et al., 2007; Komárková et al., 2011; Negrila, 2010; or Van den End, 2008). However, to the best of our knowledge, there is no empirical study focusing on the determinants of bank vulnerability to a bank run. This paper therefore attempts to fill this gap.

There are several reasons that we focus on the Visegrad countries (Czechia, Hungary, Poland, and Slovakia). First, the national financial systems can be characterized as bank-oriented and concentrated on a model of universal banking. Banks have a dominant role in financial intermediation and banks are also important for the whole economies of these countries. One can illustrate this on the indicator of total banking assets over GDP. The values from 2015 show $127 \%$ in Czechia, 113\% in Hungary, $85 \%$ in Poland and Slovakia.

Second, banking sectors in the Visegrad (hereafter V4) countries are dominated by foreign banks and financial conglomerates that are often present and systematically important in many countries. Therefore, financial stability of these banking sectors and their ability to withstand sudden deposit withdrawal can be affected also by strategies implemented by multinational financial conglomerates and by the financial stability and credibility of both the parent company and its subsidiaries.

Third, due to aforementioned characteristics the banking sectors in the V4 countries are sufficiently homogeneous for application of identical methodology and variables. On the other hand, they slightly differ in structure and macroeconomic conditions. Hence, we meet the requirements for an insightful cross-country comparison and can expect some differences in explaining vulnerability of banks to a potential bank run.

Fourth, we are convinced that the risk of bank run in the V4 countries is not only theoretical and imaginary eventuality but deserves a serious research interest. Our view is also supported by recent evidence. Besides the well-known examples of bank runs in developed countries such as Northern Rock 
in the UK, IndyMac and Wachowia in the US or DSB Bank in the Netherlands bank runs occurred also in central and Eastern Europe. The most recent episodes can be found in Bulgaria (Corporate Commercial Bank and First Investment Bank in June 2014) and in Poland (SK Bank in December 2015).

Therefore, the aim of the paper is to examine potential bank runs in the $\mathrm{V} 4$ countries. In particular, we determine maximum volume of deposits that can be withdrawn from each individual bank and identify the determinants of banks' sensitivity to a bank run. The paper is structured as follows. The next section provides theoretical background on bank liquidity and bank runs. Then, we focus on the methodology, data and results of the analysis. The final section offers concluding remarks.

\section{Bank Liquidity and Bank Runs}

Each bank has to be liquid, which means that it should have sufficient financial resources to meet its obligations as they fall due or be able to obtain such funds at reasonable costs. Insufficient bank liquidity may lead to a situation in which the majority of depositors intend to withdraw their funds, which will in turn result in a run on the bank.

Banks have been always plagued by the problem of bank runs. Freixas and Rochet (1997) define a bank run as a situation wherein depositors observe large withdrawals from their bank, fear bankruptcy and respond by withdrawing their own deposits. Banks are vulnerable to runs, which can lead to closure and liquidation because they issue liquid liabilities in the form of deposit contracts but invest in illiquid assets in the form of loans. A banking panic then occurs when depositors at many or all of the banks in a region or a country attempt to withdraw their funds simultaneously (Allen \& Gale, 1998).

The theoretical literature on bank runs is primarily based on the study of Bryant (1980) and the model of Diamond and Dybvig (1983) that accentuate the fact that bank runs are selffulfilling prophecies. Two types of bank runs can be distinguished: efficient and inefficient. Given the assumption that the liquidation of some assets is costly, there are multiple equilibriums. If depositors believe that a banking panic will occur, it is optimal for each depositor to attempt to withdraw his funds. The bank will then have to liquidate some of its assets at a loss. Those depositors who withdraw initially will receive more than those who wait (given the assumption of first-come, first-served). Anticipating this, all depositors have an incentive to withdraw immediately. Such a situation may be called an inefficient bank run. Conversely, all agents withdraw their funds according to their consumption needs if no depositors believe that a panic will occur (and another equilibrium exists).

An efficient bank run is based on fundamental factors. Depositors who have information concerning an impending downturn in the business cycle may anticipate financial difficulties in the banking sector and attempt to withdraw their funds. Such behavior will precipitate the crisis (Allen \& Gale, 1998).

As bank runs are typically considered costly and adverse events for the banking sector and the whole economy, most economists and, particularly, regulators attempt to determine the best ways to prevent bank runs. One possibility is to establish a functional deposit insurance scheme. A major argument in favor of deposit insurance is that it maintains and promotes financial stability by preventing inefficient bank runs arising from asymmetric information and self-fulfilling prophecies (as in Diamond \& Dybvig, 1983). On the other hand, many studies indicate that deposit insurance fails to maintain banking stability because of moral hazard.

To a certain extent, efficient liquidity risk management can also prevent bank runs. A sufficient level of bank liquidity in the form of liquidity buffers can prevent panic sales of assets when banks face pressure caused by their need to cover investors' request to withdraw deposits or by investors' unwillingness to roll over short-term bonds issued by banks. Such buffers enhance the ability of banks to absorb external shocks (Frait \& Komárková, 2011). Fund-raising options also include strategies involving the interbank market (where banks can borrow from other banks in response to liquidity demand) and the option of relying on emergency liquidity assistance from a lender of last resort (Aspachs et al., 2005).

Therefore, in accordance with the recommendation of the Basel Committee for Banking Supervision, financial institutions should gauge their potential vulnerability to such events by conducting of stress tests (BIS, 2000). Such stress testing would enable us to determine the worst-case scenario for each 
bank in the banking sectors of the V4 countries and to investigate which factors affect the sensitivity of individual banks to a bank run.

\section{Methodology and Data}

First, we will evaluate the level of liquidity risk for each bank in the sample using the most commonly employed liquidity ratio, the liquid asset ratio. The liquid asset ratio (LAR) is the share of liquid assets in total assets (Equation 1).

$$
L A R=\frac{\text { liquid assets }}{\text { total assets }} * 100(\%)
$$

This ratio should give us information on a bank's capacity to absorb a general liquidity shock. As a general rule, the higher the ratio, the higher the capacity to absorb liquidity shock is, provided that market liquidity is the same for all banks in the sample. We use the BankScope measure of liquid assets which includes cash, government bonds, short-term claims on other banks (including certificates of deposit), and where appropriate the trading portfolio.

As a next step, we will simulate a run on a bank by the withdrawal of a certain volume of clients' deposits. There are studies that focus on modeling bank runs in the Czech (Komárková et al., 2011), Slovak (Jurča \& Rychtárik, 2006), Romanian (Negrila, 2010), Austrian (Boss et al., 2004 and 2007) and Luxembourg (Rychtárik, 2009) banking sectors. These studies modeled potential bank runs in slightly different ways. Komárková et al. (2011) simulated deposit withdrawals of an average of $11 \%$ of total deposits. Negrila (2010) tested the impact of the sudden withdrawal of $20 \%$ of individual deposits and $10 \%$ of corporate deposits. Boss et al. (2004) stressed liquidity ratios via a scenario in which nonbank customers would withdraw $20 \%$ of their deposits; they continued their analysis by testing the impact of a withdrawal of $50 \%$ of nonbank deposits (Boss et al., 2007). Jurča and Rychtárik (2006) considered a $20 \%$ decline in client deposits. Rychtárik (2009) measured the sensitivity of banks to the withdrawal of $20 \%$ of client deposits.

Based on the above cited studies, we will simulate the bank run by a $20 \%$ withdrawal of deposits; this haircut will be applied to total deposits without accounting for the agreed maturities of different types of deposits. This simulation is in accordance with time structure of deposits in the V4 countries at the beginning of 2015. According to national central banks' statistics the sight deposits accounted for $69.6 \%$ of all deposits in Czechia, $49.2 \%$ in Hungary, $44.7 \%$ in Poland and $51.4 \%$ in Slovakia. Our model of the bank run also conforms to the course of the aforementioned bank runs in Bulgaria and Poland.

To calculate the stressed value of the liquid asset ratio, we have to deduct the volume of withdrawn deposits, i.e., $20 \%$ of clients' deposits, from liquid assets. Banks must use liquid assets to repay deposits. Moreover, the volume of total assets also declines as a result of this operation. Equation 2 captures these modifications.

$$
\text { LARS }=\frac{\text { liquid assets }-0.2^{*} \text { deposits }}{\text { total assets }-0.2^{*} \text { deposits }} * 100(\%)
$$

Next, we will compare this stress value of the liquid asset ratio $\left(\mathrm{LAR}_{\mathrm{S}}\right)$ to the baseline value of this ratio $\left(L A R_{B}\right.$, i.e., $\left.L A R\right)$. The percentage change of the ratio LAR between its stress and baseline values will be calculated according to Equation 3. The results will reveal the magnitude of the relative changes between the stress and baseline values, which will enable us to determine which bank is the most vulnerable. Since the values of $L A R_{S}$ are obviously always less than the values of $\mathrm{LAR}_{\mathrm{B}}$, we will quantify the extent of the percentage change in positive numbers. We will also be able to determine the worst-case scenario for each bank in the sample, i.e. the maximum volume of deposits that can be withdrawn from the bank.

$$
\Delta L A R=\frac{L A R S-L A R B}{L A R B} * 100(\%)
$$

Finally, to identify determinants that affect the worst-case scenario for banks in the V4 countries, we will use panel data regression analysis (Equation 4).

$$
\Delta D_{i t}=\alpha+\beta^{\prime} \cdot X_{i t}+\delta_{i}+\varepsilon_{i t}
$$

where $\Delta D_{i t}$ is the maximum possible deposit withdrawal for bank $i$ at time $t$ (expressed as a percentage of deposits of bank i at time $t), \boldsymbol{X}_{i t}$ is vector of explanatory variables for bank $\mathrm{i}$ at time $\mathrm{t}, \boldsymbol{\alpha}$ is a constant, $\boldsymbol{\beta}^{\prime}$ is a row vector of coefficient 
that represents the slope of explanatory variables, $\delta_{i}$ represents fixed effects for bank $\mathrm{i}$, and $\varepsilon_{i}$ is the error term. The maximum deposit withdrawal refers to the situation in which the stressed value of LAR is equal to zero i.e. $L_{A R}=0$. This is related to the situation when the numerator of Equation 2 is equal to zero, i.e. when the maximum deposit withdrawal is equal to the available liquid assets of the bank. The panel regression is applied in order to involve the whole national banking sector into one model. Although we work with bank-level data the banks perform under common regulation and supervision framework and face the same macroeconomic conditions.

It is evident that the most crucial task is to determine the appropriate explanatory variables. Although the liquidity problems of certain banks during the global financial crisis re-emphasized that liquidity is very important for the functioning of financial markets and the banking sector, an important gap nevertheless exists in the empirical literature on liquidity and its measurement. This is especially true for the determinants of bank sensitivity to any stress scenario; to the best of our knowledge, there is no empirical study focusing on the determinants of bank vulnerability to a bank run. Therefore, in our literature review, we will focus on empirical studies that sought to identify the determinants of selected liquidity ratio. Studies have reported that some determinants have positive effects in some countries but negative effects in others. In essence, the potential determinants of bank liquidity can be divided into two groups: macroeconomic and bank-specific variables.

Many studies have tested the impact of gross domestic product (GDP) on bank liquidity. This impact may be either positive (such as in Fielding \& Shortland, 2005; Vodová 2013; 2015), which signals that a cyclical downturn should reduce banks' expected transaction demand for money and therefore lead to decreased liquidity, or negative, which means that banks hold a smaller amount of liquidity in periods of stronger economic growth (as demonstrated by Aspachs et al., 2005; Dinger 2009; Grant, 2012; Moore, 2010; Rauch et al., 2010; Vodová, 2013).

Another macroeconomic variable, the unemployment rate, is connected with the demand for loans and typically acts as a proxy for the general health of the economy. However, its impact on bank liquidity is again mixed - positive according to Munteanu (2012) and Vodová (2013) and negative as in Munteanu (2012); Rauch et al. (2010); Vodová (2013; 2015). The negative impact of unemployment has more of economic rationality as it is in accordance with the fact that banks suffer from a reduction in solvency and create lower liquidity in troubled economic times. The positive impact can be particularly revealed in times of economic stability and relatively stable unemployment rate.

The levels of various types of interest rates also appear to be important: the monetary policy interest rate, money market interest rate, interbank interest rate and lending interest rate. Again, in some countries, the effect of the interest rate on bank liquidity is positive (e.g., Agénor et al., 2000; Bunda \& Desquilbet, 2008; Dinger, 2009; Fielding \& Shortland, 2005; Lucchetta, 2007; Moore, 2010; Munteanu, 2012; Vodová, 2013; 2015), while in other countries or periods, the interest rate adversely affects bank liquidity (see Aspachs et al., 2005; Bunda \& Desquilbet, 2008; Grant, 2012; Lucchetta, 2007; Moore, 2010; Munteanu, 2012; Rauch et al., 2010; or Vodová, 2013 and 2015). The same, e.g., mixed results, can also be observed for the interest margin - a negative impact in Aspachs et al. (2005) or Grant (2012); while a positive link is reported by Vodová (2015). A positive relationship between interest rates and bank liquidity is connected with the problem of credit rationing, while a negative link indicates that if lending activity is more profitable, banks will hold a smaller buffer of liquid assets and prefer to provide loans.

Recent studies have also focused on the impact of the financial crisis on bank liquidity, which may be again either negative (such as in Bunda \& Desquilbet, 2008; Moore, 2010; Vodová, 2013 and 2015) or positive (as it was demonstrated by Berrospide, 2013; Cornet et al., 2012; Moore, 2010). The negative link between the financial crisis and bank liquidity is obvious: a financial crisis can be the result of poor bank liquidity; poor bank liquidity can also be a result of a financial crisis. However, a positive relationship between the crisis and bank liquidity can also be explained: during the crisis, banks devoted greater attention to cautious liquidity risk management and held higher buffers of liquid assets. Thus, during a crisis, bank liquidity may even increase. Such behavior may also be associated with 
liquidity hoarding (Acharya \& Merrouche, 2013; Berrospide, 2013; Kapadia et al., 2012).

Among other macroeconomic factors, the type of exchange rate regime is an important consideration. According to Bunda and Desquilbet (2008), in extreme regimes such as pure floating and currency board and dollarized economies, banks are more liquid than in intermediate regimes. Additional relevant factors are the share of public expenditures in GDP (which Bunda \& Desquilbet, 2008, demonstrated to have a positive effect on bank liquidity); the volatility of the cash to deposit ratio (where higher volatility increases bank liquidity according to Agénor et al., 2000); and the probability of obtaining support from a lender of last resort in the event of a liquidity shortage (which reduces incentives to hold liquid assets as demonstrated by Aspachs et al., 2005). Fielding and Shortland (2005) also demonstrated that banks hold excessive liquid reserves in periods of political instability.

Although banks within a given country face to the same macroeconomic conditions, their liquidity levels differ. The reason lies in different bank-specific conditions. Many bank-specific variables such as the size of the bank, its capital adequacy and profitability, and the quality of its loan portfolio, have been analyzed in individual studies.

Two different theories explain the link between capital adequacy and bank liquidity (Berger \& Bouwman, 2009). The financial fragility-crowding-out hypothesis suggests that bank capital may impede liquidity creation by making the bank's capital structure less fragile. A fragile capital structure encourages the bank to commit to monitoring its borrowers, and, hence, allows it to extend loans. Additional equity capital makes it more difficult for less fragile banks to commit to monitoring, which in turn hampers the bank's ability to create liquidity. Capital may also reduce liquidity creation because it crowds out deposits. This negative relationship between bank liquidity and capital adequacy has been reported by Berger and Bouwman (2009), Diamond and Rajan (2001), Dinger (2009), Distinguin et al. (2013), Gorton and Winton (2000), Lei and Song (2013), Munteanu (2012), and Vodová (2013 and 2015). An alternative view - the risk absorption hypothesis - is related to banks' role as risk transformers and emphasizes that higher capital improves banks' ability to absorb risk and hence their ability to create liquidity. This theory has been confirmed by Berger and Bouwman (2009), Berrospide (2013), and Vodová (2013; 2015).

Banks that are net lenders on the interbank market tend to be smaller than borrower banks (Lucchetta, 2007). Most studies agree that the size of banks is negatively correlated with their liquidity. Large banks are less willing to hold liquid assets because they rely more on funds from the interbank market (Berrospide, 2013; Cornet et al., 2012; Dinger, 2009; Vodová, 2013).

The quality of a bank's credit portfolio is also relevant: with a higher share of nonperforming loans, banks begin to offset higher credit risk with more cautious liquidity risk management (Vodová, 2013; 2015). Moreover, greater portion of nonperforming loans in portfolio has a negative impact on bank's profitability. The link between bank profitability and liquidity may, again, be either negative (such as in Grant, 2012 or Vodová, 2013) or positive (Vodová, 2013). Bank profitability having a negative influence on liquidity is consistent the standard finance theory, which emphasizes the negative correlation between liquidity and profitability. Bank profitability may be indicative of strategy whereby liquidity-constrained banks need to accumulate profits that can then be invested in liquid assets and thus used as a source of liquidity.

The selection of explanatory variables is based on the studies cited above. We considered whether the use of a particular variable is economically reasonable in case of the V4 countries. We also considered which other factors could influence the sensitivity of banks to a bank run.

We can expect that the most vulnerable banks should be those with an insufficient amount of client deposits to finance their activities. Therefore, they need to use other sources of funding. This assumption is reflected in application of the loan-to-deposit and netinterbank-position ratios. LODE measures the structural mismatch between borrowing and lending to/from customers. Banks that show large funding gap (very high LODE) are more exposed to liquidity risk. Vulnerable banks should also focus more on providing loans to non-bank customers; therefore, they have a smaller buffer of liquid assets. Bank liquidity and profitability are closely linked. If banks 
seek only to achieve maximum profitability, they provide relatively more loans to nonbank customers and use more funds from the interbank market to finance their activities, which makes them considerably more vulnerable in the event of a crisis (which can be accompanied by, e.g., a bank run). Conversely, the safest strategy is to hold a sufficient buffer of liquid assets (i.e., to have high value for the LAR ratio), to provide loans to non-bank customers on a rational basis and to finance lending activity mainly from client deposits. These ideas, together with the findings of studies focusing on the determinants of liquidity ratios, are reflected in the list of variables employed in this study (Tab. 1).

\section{Tab. 1: Variables Definition}

\begin{tabular}{l|c} 
Bank-specific variables & Source \\
\hline CAP: share of equity in total assets of the bank & BankScope \\
\hline NPL: share of non-performing loans in total volume of loans & BankScope \\
\hline ROA: share of net profit in total assets of the bank & BankScope \\
\hline TOA: logarithm of total assets of the bank & BankScope \\
\hline NITA: share of net interbank position in total assets of the bank & BankScope \\
\hline LODE: share of loans in deposits of the bank & BankScope \\
\hline LOTA: share of loans in total assets of the bank & BankScope \\
\hline Macroeconomic and sectoral variables & \\
\hline GDP: growth rate of gross domestic product (GDP volume \% change) & IMF \\
\hline INF: inflation rate (CPI \% change) & IMF \\
\hline IRB: interest rate on interbank transactions & IMF \\
\hline IRL: interest rate on loans & CNB, MNB, NBP, \\
\hline IRM: difference between interest rates on loans and deposits & CNB, MNB, NBP, \\
\hline MIR: monetary policy interest rate & NBS \\
\hline UNE: unemployment rate & $\begin{array}{c}\text { CNB, MNB, NBP, } \\
\text { ECB }\end{array}$ \\
\hline
\end{tabular}

We considered seven bank-specific factors and seven macroeconomic factors. We do not have exact expectations concerning the impact of these factors on a bank's sensitivity to a bank run, as this is the first study to investigate this problem. The macroeconomic data were provided by the International Financial Statistics of the International Monetary Fund (IMF), European Central Bank (ECB), Czech National Bank (CNB), National Bank of Poland (NBP), Hungarian National Bank (MNB) and National Bank of Slovakia (NBS). The bank specific data were obtained from the unconsolidated balance sheet and profit and loss data recorded in the BankScope database.
We used data over the period 2000-2014. Tab. 2 provides additional details on the sample. Despite the relatively small number of banks in the sample, the data set includes significant parts of all banking sectors (usually more than $70 \%$ of total assets of the banking sector). Due to the homogeneity of the data set, we include only data from commercial banks. We exclude branches of foreign banks, mortgage banks, building societies and state banks with special purposes (such as Českomoravská záruční a rozvojová banka, Slovenská záručná a rozvojová banka, Česká exportní banka, Exim banka, Magyar Fejlesztési Bank or Bank Gospodarstwa Krajowego). The national panels 


\begin{tabular}{|c|c|c|c|c|c|c|c|c|c|c|c|c|c|c|c|}
\hline \multirow{2}{*}{ Indicator } & \multicolumn{15}{|c|}{ Values for Individual Years } \\
\hline & 00 & 01 & 02 & 03 & 04 & 05 & 06 & 07 & 08 & 09 & 10 & 11 & 12 & 13 & 14 \\
\hline \multicolumn{16}{|c|}{ Czechia } \\
\hline Total no. of banks & 40 & 38 & 37 & 35 & 35 & 36 & 37 & 37 & 37 & 39 & 41 & 44 & 43 & 44 & 45 \\
\hline No. of obs. banks & 15 & 15 & 16 & 16 & 16 & 16 & 13 & 13 & 12 & 12 & 13 & 13 & 14 & 14 & 14 \\
\hline Share of asset (\%) & 59 & 68 & 74 & 74 & 74 & 72 & 75 & 75 & 66 & 68 & 68 & 75 & 69 & 72 & 74 \\
\hline \multicolumn{16}{|c|}{ Hungary } \\
\hline Total no. of banks & 40 & 41 & 39 & 38 & 35 & 34 & 37 & 38 & 36 & 35 & 35 & 35 & 35 & 37 & 39 \\
\hline No. of obs. banks & 14 & 18 & 23 & 24 & 26 & 28 & 28 & 27 & 25 & 24 & 21 & 19 & 20 & 19 & 14 \\
\hline Share of asset (\%) & 72 & 74 & 84 & 86 & 88 & 88 & 88 & 87 & 88 & 88 & 87 & 87 & 86 & 86 & 82 \\
\hline \multicolumn{16}{|c|}{ Poland } \\
\hline Total no. of banks & 73 & 71 & 62 & 60 & 54 & 54 & 51 & 50 & 52 & 49 & 49 & 47 & 45 & 41 & 38 \\
\hline No. of obs. banks & 22 & 23 & 26 & 26 & 28 & 28 & 26 & 27 & 30 & 35 & 35 & 35 & 35 & 33 & 38 \\
\hline Share of asset (\%) & 66 & 75 & 80 & 71 & 78 & 79 & 76 & 73 & 73 & 73 & 73 & 73 & 78 & 83 & 77 \\
\hline \multicolumn{16}{|c|}{ Slovakia } \\
\hline Total no. of banks & 23 & 21 & 20 & 21 & 21 & 23 & 24 & 26 & 26 & 26 & 29 & 32 & 29 & 29 & 29 \\
\hline No. of obs. banks & 9 & 11 & 11 & 11 & 11 & 11 & 12 & 12 & 12 & 12 & 11 & 11 & 9 & 9 & 9 \\
\hline Share of asset (\%) & 64 & 72 & 69 & 72 & 70 & 73 & 76 & 79 & 85 & 85 & 84 & 85 & 78 & 79 & 79 \\
\hline
\end{tabular}

Source: Authors' compilation based on statistics of national central banks

are unbalanced because some banks do not report or exist over the full period of analysis.

\section{Results and Discussion}

The first part of this section presents the median values of the baseline and the stress values of the liquid asset ratio and the worstcase scenario (bank run) for each bank in the sample. The second part of this section focuses on factors that determine vulnerability of banks to the bank run.

\subsection{Scenario Analysis}

The median values of the baseline and stress values of the share of liquid assets in total assets (LAR) are presented in Fig. 1. As a higher value of this ratio means higher liquidity, it is evident that bank liquidity in all V4 countries decrease during the analyzed period. However, the trends differ between countries. The liquidity of Czech banks declined during the period 2000-2007, due to the mutual effect of higher lending activity by Czech banks and the decrease of balances with central banks and other banks (CNB, 2008). After a slight improvement in liquidity during 2008-2011, liquidity subsequently decreased in recent years. As the largest share of liquid assets in the Czech banking sector consists of government securities, it is evident that the development of liquid assets as a whole is strongly influenced by their volume held by banks (CNB, 2012; 2014).

When it comes to the Hungarian banking sector, it was affected by the financial crisis already in 2007. According to HFSA (2009), the internal, structural features of the banking sector have evolved over the years. These specifics area very high loan-to-deposit ratio, long net foreign currency position which resulted from the growing ratio of foreign currency loans (about one third of loans to non-financial companies and even two thirds of loans to households). Moreover, some Hungarian banks provided loans to foreign customers especially from CEE countries which were financed partly by local retail deposits. These structural weaknesses gained special importance due to the worsening financial and economic conditions.

The situation was very similar in the Polish banking sector. The liquid asset ratio fluctuated 
only slightly during the period 2000-2006. In 2007, the liquidity started to decline. Banks financed increased demand for loans both to households and non-financial companies also by reduction of the part of liquid assets. Mainly small and medium sized banks with a poorly developed deposit base used funds from the interbank market (PFSA, 2008). In 2008, the increase in lending activities continued. However, important structural weaknesses occurred: the Polish banking sector as a whole became net borrower in the interbank market; household debts in foreign currency grew rapidly (up to more than $25 \%$ of total loan portfolio (PFSA, 2009)); and a very high loanto-deposit ratio.

The liquid asset ratio of Slovak banks fluctuated only slightly during the period 20002008; however, this ratio declined sharply in 2009. The year 2009 is definitely a turning point for the banking sector: the economic crisis adversely effected sectors in which Slovak banks had significant credit exposure. Moreover, activities in the interbank market changed dramatically. While Slovak banks had mostly received deposits from foreign banks and then conducted sterilization operations with the National Bank of Slovakia in previous years, after the euro changeover, these operations lost their former significance. Most banks borrowed funds from other banks with the Eurosystem and predominantly invested these funds in government bonds and, in some cases, in the interbank market, mainly in transactions with parent banks (NBS, 2010). After a further decline in bank liquidity, we observe slight improvements in 2014.

A lower stressed value for the liquid asset is a clear signal of a liquidity outflow. Median values of the stressed liquid asset ratio for Czech banks are positive for the full period. This means that Czech banking sector as a whole should be well prepared for a bank run, simulated by a withdrawal of $20 \%$ of client deposits. Of course, individual banks in individual years could have problems coping with such a crisis; noteworthy in this regard are Equa bank in 2011-2014, Česká spořitelna

\section{Fig. 1: Baseline and Stressed Values of the Liquid Asset Ratio for Banks in the V4 Countries (in \%)}
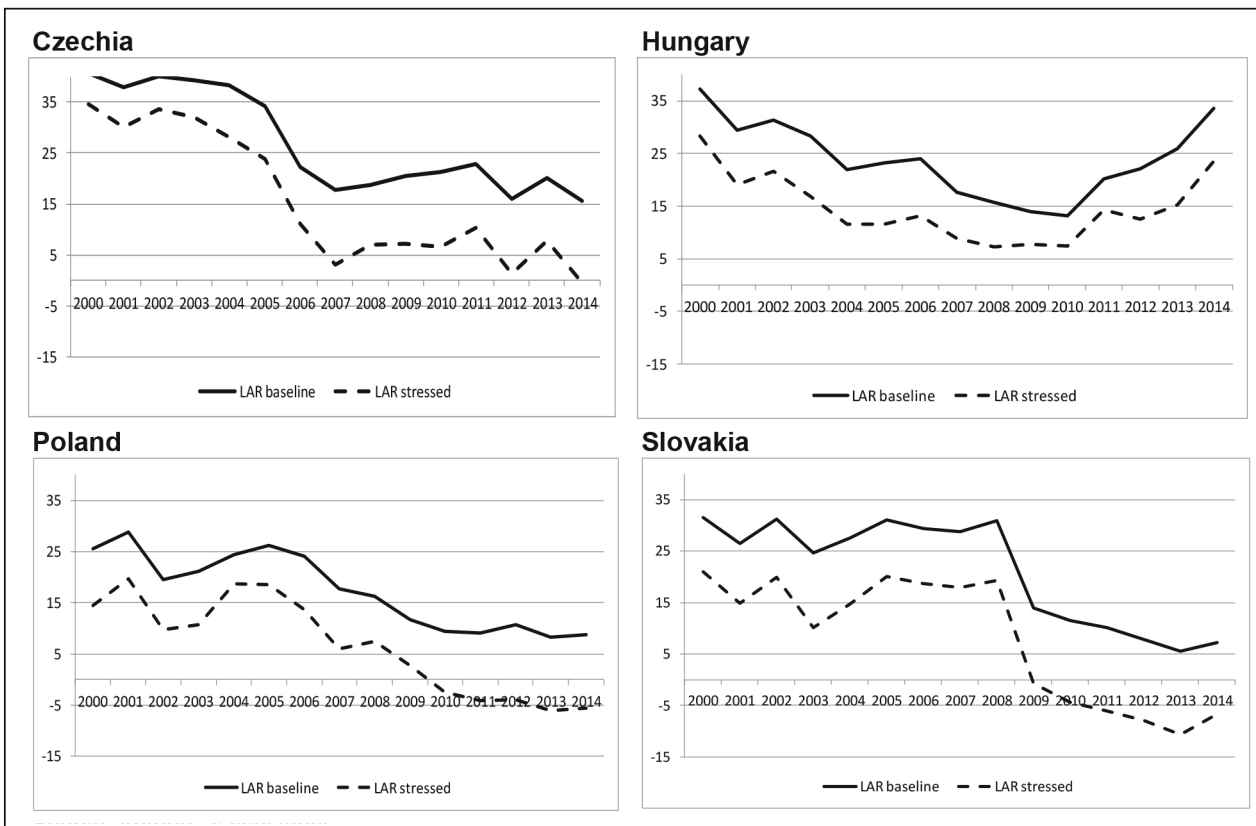

Source: Authors' calculations 
in 2006-2008 and 2014, ČSOB in 2006-2008 and 2010, GE Money Bank in 2007-2009, J\&T banka and Expobanka in 2012-2014, or Raiffeisenbank in 2010-2013.

Also Hungarian banking sector seems to be quite resilient which is reflected in the positive median values of the stressed liquid asset ratio. Only a few banks would not be able to face such development, e.g. Budapest Bank, CIB Bank, Raiffeisen Bank, Sopron Bank Burgenland and Credigen bank.

However, in the case of Slovakia and Poland, the situation would be considerably worse. Median values of the stressed liquid asset ratio are positive only in the period 20002008 for Slovakia and 2000-2009 for Poland. Beginning in 2009, Slovak banks on average would not be able to finance a $20 \%$ withdrawal of client deposits. During this second half of the analyzed period, only ČSOB and Komerční banka Bratislava in 2009-2011, Poštová banka and Citibank in 2009, Sberbank and Privatbanka in 2011 and UniCredit Bank in 2010 would have been able to cover $20 \%$ deposit withdrawals with using their liquid assets without necessity of converting less liquid assets to cash. During 2009-2014, other banks would not have had sufficient liquidity to fund the required deposit withdrawals.
Started in 2010, Polish banking sector as a whole would not be able to withstand the withdrawal of $20 \%$ of client deposits, with the exception of Raiffeisen Bank Polska, BPH Bank, Nordea Bank, Bank Polskiej Spoldzielczosci, SGB Bank and Mercedes-Benz Bank.

Regarding the average impact of a bank run on the liquid asset ratio, we observe a gradually rising negative effect of the simulated bank run on the liquidity of banks over the entire analyzed period (see Tab. 3 for average values). It is evident that the financial crisis increased the sensitivity of all banks to a possible bank run. However, it is surprising that banks in three V4 countries would have been the most vulnerable only recently. In particular, Czech banks in 2012 and Slovak and Polish banks in 2013. It seems that with the exception of Hungary, there is a significant time lag between the emergence of the financial crisis and its impacts on liquidity of banks. We can also see that the impact of the crisis on banks differs among analyzed countries.

Our aim is also to determine the maximum volume of deposits that can be withdrawn from individual banks, i.e., to identify the worst-case scenario for each bank. The threshold volume of deposits was calculated under the assumption that the bank can use all of its liquid assets to

\section{Tab. 3: Average Decrease in the Liquid Asset Ratio in the V4 Countries (in \%)}

\begin{tabular}{l|r|r|r|r|r|r|r|r|r|r|r|r|r|r|r} 
& \multicolumn{10}{|c|}{ Values for Individual Years } \\
& $\mathbf{0 0}$ & $\mathbf{0 1}$ & $\mathbf{0 2}$ & $\mathbf{0 3}$ & $\mathbf{0 4}$ & $\mathbf{0 5}$ & $\mathbf{0 6}$ & $\mathbf{0 7}$ & $\mathbf{0 8}$ & $\mathbf{0 9}$ & $\mathbf{1 0}$ & $\mathbf{1 1}$ & $\mathbf{1 2}$ & $\mathbf{1 3}$ & $\mathbf{1 4}$ \\
\hline $\mathrm{CZ}$ & 9 & 20 & 20 & 27 & 30 & 44 & 56 & 85 & 77 & 63 & 76 & 65 & 137 & 104 & 95 \\
\hline $\mathrm{HU}$ & 40 & 51 & 32 & 41 & 37 & 33 & 34 & 39 & 65 & 89 & 81 & 52 & 70 & 80 & 43 \\
\hline $\mathrm{PL}$ & 40 & 36 & 46 & 36 & 45 & 35 & 48 & 62 & 52 & 135 & 194 & 228 & 180 & 213 & 207 \\
\hline $\mathrm{SK}$ & 33 & 44 & 36 & 59 & 47 & 36 & 37 & 38 & 38 & 105 & 137 & 160 & 202 & 294 & 192 \\
\hline
\end{tabular}

\section{Tab. 4: Maximum Deposit Withdrawal in the V4 Countries (in \%)}

\begin{tabular}{|c|c|c|c|c|c|c|c|c|c|c|c|c|c|c|c|}
\hline & \multicolumn{15}{|c|}{ Values for Individual Years } \\
\hline & 00 & 01 & 02 & 03 & 04 & 05 & 06 & 07 & 08 & 09 & 10 & 11 & 12 & 13 & 14 \\
\hline $\mathrm{CZ}$ & 124 & 68 & 69 & 60 & 50 & 41 & 35 & 23 & 30 & 27 & 27 & 31 & 22 & 30 & 19 \\
\hline $\mathrm{HU}$ & 23 & 33 & 27 & 34 & 35 & 24 & 25 & 26 & 49 & 38 & 42 & 29 & 43 & 37 & 30 \\
\hline PL & 45 & 46 & 40 & 50 & 48 & 54 & 41 & 32 & 36 & 25 & 15 & 13 & 18 & 12 & 12 \\
\hline SK & 44 & 37 & 41 & 31 & 36 & 44 & 42 & 43 & 44 & 19 & 15 & 12 & 9 & 7 & 11 \\
\hline
\end{tabular}


meet depositors' demands for cash. The data in Tab. 4 indicate the median values of maximum deposit withdrawal for banking sectors in the V4 countries. The figures on ability of individual banks to cover deposit withdrawals, i.e., the maximum deposit withdrawal (as a percentage of deposits) that the banks would be able to survive, can be obtained from authors upon request. The results are consistent with previous findings: Czech and Hungarian banks are, on average, able to withstand larger deposit withdrawals than are Slovak and Polish banks. This conclusion has been evident since the outbreak of the financial crisis.

Of course, there are again significant differences among banks. There are banks that could only finance withdrawals of less than $10 \%$ of deposits in some years, such as Expobanka, Raiffeisenbank and UniCredit Bank in Czechia; ČSOB, OTP banka, Poštová banka, Privatbanka, Slovenská sporitelňa, Tatra banka and VúB in Slovakia; CIB Bank, Budapest bank, MagNet Hungarian Civic Bank, Porsche bank and Sopron Bank Burgenland in Hungary and Alior Bank, Bank BGZ, BOS Bank, Credit Agricole Bank, DNB Bank, FM Bank, Getin Noble, Ideal Bank, ING Bank, Meritum Bank, Plus Bank, Bank Pocztowy, Santander Consumer Bank and Toyota bank in Poland. If customers sought to further withdraw their deposits, the existence of these banks would be in jeopardy because of insufficient liquidity. The depositors of Slovak Tatra banka or Polish Getin Noble would be able to withdraw only $1 \%$ of their deposits or even less in some years which is particularly alarming. Conversely, at least in some years, the depositors of certain other banks would be able to withdraw more than $50 \%$ of their deposits.

\subsection{Panel Data Regression Analysis}

To identify the factors that determine the sensitivity of banks to a bank run, we employ an econometric package EViews 9. After tests of stationarity, normality and multicollinearity, we proceed with regression estimation. We estimated Equation 4. First we included all explanatory variables that might have an effect on the dependent variable (all explanatory variables considered in the analysis are those which are presented in Tab. 1).

Some bank-specific variables as well as some macroeconomic factors could influence ability of banks to withstand sudden deposit withdrawal also with a certain time lag. For example, the deterioration in overall economic development probably does not increase bank vulnerability immediately, because the bank has sufficient volume of liquid assets and its financial situation is stable. More likely, the buffer of liquid assets is gradually decreasing due to worsening economic conditions. The bank which was initially liquid may gradually become illiquid. Likewise, the worsening quality of loan portfolio usually is manageable in shortterm. The vulnerability of bank increases if troubles with repaying the loans continues and escalates. The effect of profitability can also be more pronounced with some delay as actual profits generated by illiquid assets will affect the future liquidity risk of the bank. Therefore, in economically rational cases we experimented with lagged variables in model estimations. The lags were used for the following variables CAP, NPL, ROA, GDP, UNE. The maximum time lag was set to two years for GDP growth rate and one year for remaining lagged variables. Similar approach to application of lagged variables can be found in e.g. Berrospide (2013), Vodová (2013) or Adusei (2015).

To reduce the number of explanatory variables, we used information criteria (Akaike, Schwarz and Hannan-Quinn). Our aim was to find a regression model with a high value of the adjusted coefficient of determination in which all the variables involved are statistically significant. The results for Czech banks are recorded in Tab. 5.

The explanatory power of the model is quite high. The sensitivity of Czech banks to the possible bank run, or, more preciously, the maximum deposit withdrawal for individual Czech banks, is determined primarily by two bank-specific and two macroeconomic factors.

Focusing on bank-specific factors, the bank's profitability and liquidity are important. The share of loans to deposits (LODE) is an indirect measure of bank liquidity. This ratio relates illiquid assets to liquid liabilities. The higher this ratio, the less liquid the bank is. The negative sign of the regression coefficient is consistent with the fact that the lower the value of the LODE ratio (and thus the higher the bank liquidity), the greater the deposit withdrawal the bank is able to withstand.

The positive link between bank profitability measured by return on assets (ROA) and the ability of the bank to face a bank run may be 
Tab. 5: Factors Affecting the Sensitivity Banks to a Bank Run in Czechia

\begin{tabular}{l|c|c}
\multicolumn{1}{c|}{ Variable } & Coefficient & Standard Deviation \\
\hline Constant & $-1.8521^{*}$ & 0.3242 \\
\hline ROA (-1) & $0.0346^{* *}$ & 0.0097 \\
\hline LODE & $-0.0039^{*}$ & 0.0006 \\
\hline IRL & $0.2147^{*}$ & 0.0459 \\
\hline UNE(-1) & $-0.1049^{*}$ & 0.0235 \\
\hline Adjusted R2 & \multicolumn{2}{|c}{0.5591} \\
\hline Durbin-Watson statistics & 1.8682 \\
\hline Total panel observations & \multicolumn{2}{|c}{172} \\
\hline
\end{tabular}

Source: Authors' calculations

Note: The starred coefficient estimates are significant at the $1 \%\left(^{*}\right), 5 \%\left({ }^{* *}\right)$ or $10 \%\left({ }^{* \star *}\right)$ level.

somewhat surprising. However, profitability is one of the key factors of a bank's financial stability. This variable is lagged by two years, which means that banks that were financially stable in the past are much safer even in the event of a sudden deposit withdrawal.

Among the macroeconomic factors, two variables are statistically significant: the interest rate on loans (IRL) and unemployment rate (UNE). The interest rate on loans is likely connected with bank profitability. With a higher interest rate on loans, a bank's lending becomes more profitable. Furthermore, with higher accumulated profit, the bank is better able to withstand the emergency of a crisis.

The unemployment rate is the last statistically significant variable. Given an increase in the unemployment rate in the previous year, bank customers are able to withdraw a smaller portion of their deposits. This variable can act as a proxy for the general health of the economy. Therefore, with an increase in the unemployment rate (and given past deterioration of macroeconomic conditions) means that banks are more vulnerable to possible bank runs.

Determinants of the maximum deposit withdrawals for Hungarian banks are presented in Tab. 6. Four variables are statistically significant: size of the bank, loan-to-deposit ratio, share of net interbank position in total assets and the unemployment rate. The explanatory power is slightly higher than for the Czech banking sector.

Two variables are the same as for Czech banks: loan-to-deposit ratio (LODE) and the unemployment rate (UNE). The share of net interbank position in total assets (NITA) reflects the fact if the bank is a net lender or a net borrower on the interbank market. The positive sign of the regression coefficient signals that net lenders are safer in case of sudden deposit withdrawal. It is obvious as the net lenders operate with abundance of clients' deposits and loans provided on the interbank market usually represent liquid assets.

Size of the bank (TOA) also matters in the Hungarian banking sector. Large banks are less vulnerable to a potential bank run than small banks. This finding is in accordance with Berger and Bouwman (2009) and stems from the fact that large banks in general have more established position on the interbank market and, therefore, better access to funds from this market. Moreover, large banks can use a wider range of sources of funding than small banks. For example, large banks are usually affiliated with a financial conglomerate and, thus, intragroup fund transfers are possible and available.

The ability of Polish banks to withstand the deposit withdrawal is determined mainly by their capital adequacy (CAP), position on the interbank market (NITA), the way how they finance their lending activity (LODE) and the general economic conditions (expressed e.g. by the rate of unemployment - UNE). The results are recorded in Tab. 7 .

Two bank-specific variables (NITA and LODE) and one macroeconomic factor (UNE) have the same impact on the vulnerability of banks as it was explained above for Czech and Hungarian banks. The last statistically significant 
Tab. 6: Factors Affecting the Sensitivity of Banks to a Bank Run in Hungary

\begin{tabular}{l|c|c}
\multicolumn{1}{c|}{ Variable } & Coefficient & Standard Deviation \\
\hline Constant & $-638.99^{*}$ & 230.72 \\
\hline TOA & $45.415^{\star *}$ & 21.069 \\
\hline LODE & $-9.15 \mathrm{E}-07^{* * *}$ & $1.72 \mathrm{E}-06$ \\
\hline NITA & $0.0074^{*}$ & 0.0005 \\
\hline UNE & $-12.808^{\star *}$ & 7.5002 \\
\hline Adjusted R2 & \multicolumn{2}{|c}{0.6371} \\
\hline Durbin-Watson statistics & \multicolumn{2}{|c}{328949} \\
\hline Total panel observations & \multicolumn{2}{|c}{328} \\
\hline
\end{tabular}

Source: Authors' calculations

Note: The starred coefficient estimates are significant at the $1 \%\left({ }^{*}\right), 5 \%\left({ }^{* *}\right)$ or $10 \%\left({ }^{* * *}\right)$ level.

\section{Tab. 7: Factors Affecting the Sensitivity of Banks to a Bank Run in Poland}

\begin{tabular}{l|c|c}
\multicolumn{1}{c|}{ Variable } & Coefficient & Standard Deviation \\
\hline Constant & $-33.791^{*}$ & 8.0196 \\
\hline CAP & $-1.9075^{*}$ & 0.4601 \\
\hline NITA & $0.0083^{*}$ & 0.0003 \\
\hline LODE & $-0.0003^{*}$ & $3.78 \mathrm{E}-05$ \\
\hline UNE(-1) & $-0.7407^{* * *}$ & 0.4647 \\
\hline Adjusted R2 & \multicolumn{2}{|c}{0.8774} \\
\hline Durbin-Watson statistics & \multicolumn{2}{|c}{1.9209} \\
\hline Total panel observations & \multicolumn{2}{|c}{351} \\
\hline
\end{tabular}

Source: Authors' calculations

Note: The starred coefficient estimates are significant at the $1 \%\left({ }^{*}\right), 5 \%\left({ }^{* *}\right)$ or $10 \%\left({ }^{* * *}\right)$ level.

variable is capital adequacy. Looking on previous research on liquidity of Polish banks, its negative influence is not a surprising finding. According to Vodová (2013), bank liquidity decreases with capital adequacy of the bank. This link between capital adequacy and bank liquidity shows that banks offset lower capital adequacy with more cautious liquidity risk management and hold sufficient buffer of liquid assets. More liquid banks are able to repay the higher share of deposits to their depositors if needed.

The estimated coefficients that best fit the regression model for Slovak banks are presented in Tab. 8. Two bank-specific and two macroeconomic factors are important for bank sensitivity to a bank run.
As in the case of Czech banks, profitability and lending activity are also significant for Slovak banks. However, regarding bank profitability, the opposite relationship is observed. The negative influence of bank profitability (ROA) is consistent with standard finance theory which emphasizes the negative correlation between liquidity and profitability. It should be noted that ROA is lagged by one year in the model. This means that banks that earned less profit in the previous year pay much more attention to liquidity risk management, which in turn reflects in their greater capacity to withstand a possible bank run. Such banks are able to repay a higher percentage of their clients' deposits. 
It is not surprising that the second bankspecific factor, again, accounts only for the liquidity of the bank. The share of loans in total assets (LOTA) indicates what percentage of the bank's assets are tied up in illiquid loans; therefore, the higher this ratio, the less liquid the bank is. The sign of the estimated coefficient is negative, which is logical. Banks with a lower value of LOTA (i.e., banks with lower lending activity with non-bank clients) focus more on other types of banking business such as interbank loans or trading in securities. Both types of transactions increase the volume of liquid assets, which makes the bank less vulnerable to possible unforeseen deposit withdrawals.

\section{Tab. 8: Factors Affecting the Sensitivity of Banks to a Bank Run in Slovakia}

\begin{tabular}{l|c|c}
\multicolumn{1}{c|}{ Variable } & Coefficient & Standard Deviation \\
\hline Constant & $1.0361^{*}$ & 0.1181 \\
\hline ROA (-1) & $-0.0229^{* *}$ & 0.0097 \\
\hline LOTA & $-0.0084^{*}$ & 0.0017 \\
\hline IRB & $0.0278^{*}$ & 0.0088 \\
\hline UNE & $-0.0248^{*}$ & 0.0049 \\
\hline Adjusted R2 & \multicolumn{2}{|c}{0.6846} \\
\hline Durbin-Watson statistics & \multicolumn{2}{|c}{1.7886} \\
\hline Total panel observations & \multicolumn{2}{|c}{150} \\
\hline
\end{tabular}

Source: Authors' calculations

Note: The starred coefficient estimates are significant at the $1 \%\left(^{*}\right), 5 \%\left({ }^{\star *}\right)$ or $10 \%\left({ }^{* \star *}\right)$ level.

Among the macroeconomic variables considered, the interest rate on interbank transactions (IRB) and the unemployment rate (UNE) are statistically significant. The interbank interest rate can be perceived as the price of liquidity obtained on the interbank market. An increase in this price is a clear incentive to provide more interbank loans because a higher interbank interest rate makes these transactions more profitable. As interbank loans are a part of a bank's liquid assets, the bank's ability to withstand deposit withdrawal increases with larger volume of the disbursed interbank loans. This conclusion fully corresponds with the influence of the lending activity of a bank.

The impact of the unemployment rate on the ability of the bank to survive a bank run is the same as for all other V4 countries, only without any time lag. Under worsening macroeconomic conditions, banks are able to finance lower amounts of deposit withdrawals.

We can compare our results only with the findings of Vodová (2013), who analyzed the determinants of the liquid asset ratio in the V4 countries for the period from 2000 to 2011. Regarding Czech, Hungarian and Polish banks, the determinants of the holding of liquid assets are completely different from the factors that influence the sensitivity of banks to a potential bank run. For Slovak banks, the holding of liquid assets increased as the interest rate on loans increased and decreased as profitability, the unemployment rate and the capital adequacy of the bank increased. As we can see, two factors that influenced the level of bank liquidity measured by liquid asset ratio are also relevant to the sensitivity of banks to a possible bank run: bank profitability and the unemployment rate. Two other factors are different. However, both of them have some connection with bank liquidity. This confirms that the ability of banks to withstand an unforeseen deposit withdrawal is substantially determined by the level of bank liquidity. Banks that have a sufficient buffer of liquid assets are safer than other banks, particularly during periods of financial distress.

\section{Conclusions}

The aim of this paper was to determine maximum volume of deposits that can be withdrawn from banks in the V4 countries and identify the determinants of banks' sensitivity to a bank run. The analysis was performed over the period 2000-2014. 
Bank liquidity, measured by the liquid asset ratio, decreased in all countries during the analyzed period. However, the rate of change of the LAR indicator differs across the V4 banking sectors. While the change in Hungary was only $-10.5 \%$ (decrease of the median value from $33 \%$ in 2000 to $34 \%$ in 2014), the LAR in Slovakia dropped by $75 \%$ (decrease from $32 \%$ in 2000 to just $8 \%$ in 2014). The change in liquidity of the Czech banks was $-61 \%$ (decrease from $41 \%$ in 2000 to $16 \%$ in 2014 ) and the change in Poland amounted to $-65.4 \%$ (decrease from $26 \%$ to $9 \%$ ). Moreover, we identified two peculiar trends in the liquidity development. A distinct trend of the LAR deterioration can be observed between 2000 and 2009. Although some fluctuations and reversals temporarily occurred the general trend was followed in all V4 countries. Especially in Hungary and Poland, some important structural weaknesses arose during that time. In particular, a very high loan-to-deposit ratio, a high share of foreign debts, and a negative net position in the interbank market. By contrast, substantially different development of the LAR indicator can be discovered during the post-crisis period. While the median value of LAR stagnated in Czechia and Poland, the trend of deterioration continued in Slovakia. The only banking sector that showed an increase of liquidity was in Hungary.

Stress values of the liquid asset ratio indicated that although Czech and Hungarian banks have, on average, been well prepared for a potential bank run, Slovak and Polish banks have not, on average, been able to withstand a $20 \%$ withdrawal of client deposits since 2009 , respectively 2010 . In all countries, the impact of this stress scenario increased during analyzed period. The ability of individual banks to survive an unforeseen deposit withdrawal differs significantly. However, Czech and Hungarian banks are, on average, able to withstand larger deposit withdrawals than are Slovak and Polish banks.

The results of the panel data regression analysis showed that the sensitivity of commercial banks from the V4 countries to a possible bank run, or more preciously, the maximum deposit withdrawal for individual banks, is determined primarily by bank liquidity (connected with lending activity, the way of its financing and activity of the bank on the interbank market) and its profitability (for Czech and Slovak banks) and capital adequacy (for Polish banks), the size of the bank (for Hungarian banks), the interest rate (on loans for Czech banks and on interbank transaction for Slovak banks), and the unemployment rate. Although the signs, magnitudes and lags are not perfectly consistent in all V4 countries we can conclude that the banks with sufficient buffer of liquid assets operating with higher profitability and capital adequacy in environment of higher interest rates and lower unemployment are able to withstand the largest unforeseen withdrawal and most successfully face a bank run. Such characteristics naturally proved to be even more important during periods of financial distress.

There are many ways which may improve the research about determinants of banks' sensitivity to a bank run in the future. First, we can simply extend the time series and divide the analysis into pre-crisis, crisis and postcrisis periods. Another possibility is to extend the research into other banking sectors, e.g. to include other central and eastern European countries. It would be also possible to include other variables which may have effect on banks' sensitivity to a bank run.

Publication of this paper was supported by the Czech Science Foundation (Project GAČR 16-17796S, Affiliation with financial conglomerate as a determinant of performance and risk of banks). The support is gratefully acknowledged.

\section{References}

Adusei, M. (2015). The impact of bank size and funding risk on bank stability. Cogent Economics \& Finance, 3(1), 1-19. doi:10.1080/ 23322039.2015.1111489.

Agénor, P., Aizeman, J., \& Hoffmaister, A. (2000). The Credit Crunch in East Asia: What Can Bank Excess Liquid Assets Tell Us? [NBER Working Paper no. 7951]. doi:10.3386/w7951.

Acharya, V. V., \& Merrouche, O. (2013). Precautionary Hoarding of Liquidity and Interbank Markets: Evidence from the Subprime Crisis. Review of Finance, 17(1), 107-160. doi:10.1093/rof/rfs022.

Allen, F., \& Gale, D. (1998). Optimal Financial Crises. The Journal of Finance, 53(4), 1245-1284. doi:10.1111/0022-1082.00052.

Allen, F., \& Gale, D. (2000). Financial Contagion. Journal of Political Economy, 108(1), 1-33. doi: 10.1086/262109. 
Aspachs, O., Nier, E., \& Tieset, M. (2005). Liquidity, Banking Regulation and the Macroeconomy. Evidence on bank liquidity holdings from a panel of UK-residents banks. Presentation at BIS. Retrieved September 20, 2015, from http://www.bis.org/bcbs/events/ rtf05AspachsNierTiesset.pdf.

Berger, A. N., \& Bouwman, C. H. S. (2009). Bank Liquidity Creation. Review of Financial Studies, 22(9), 3779-3837. doi:10.1093/rfs/ hhn104.

Berrospide, J. (2013). Bank Liquidity Hoarding and the Financial Crisis: An Empirical Evaluation. [Finance and Economics Discussion Series of Federal Reserve Board no. 03]. doi:10.2139/ssrn.2207754.

BIS. (2000). Stress Testing by Large Financial Institutions: Current Practice and Aggregation Issues. Basel: Bank for International Settlements.

BIS. (2010). Basel III: International framework for liquidity risk measurement, standards and monitoring. Basel: Bank for International Settlements.

Blavarg, M., Nimander, P. (2002). Interbank exposures and systemic risk. Sveriges Riksbank Economic Review, 2002(2), 19-45.

Boss, M., Krenn, G., Schvaiger, M., \& Wegschaider, W. (2004). Stress Testing the Austrian Banking System. Österreichisches Bankarchiv, 52(11), 841-852.

Boss, M., Fenz, G., Krenn, G., Pann, J., Puhr, C., Scheiber, T., Schmitz, S. W., Schneider, M., \& Ubl, E. (2007). Stress Tests for the Austrian FSAP Update 2007: Methodology, Scenarios and Results. In Financial Stability Report (pp. 68-92). Vienna: Oesterreichische Nationalbank.

Bryant, J. (1980). A model of reserves, bank runs, and deposit insurance. Journal of Banking and Finance, 4(4), 335-344. doi:10.1016/03784266(80)90012-6.

Bunda, I., \& Desquilbet, J. B. (2008). The Bank Liquidity Smile Across Exchange Rate Regimes. International Economic Journal, 22(3), 361-386. doi:10.1080/10168730802287952.

CNB. (2008). Financial Market Supervision Report 2007. Praha: Czech National Bank.

CNB. (2012). Financial Market Supervision Report 2011. Praha: Czech National Bank.

CNB. (2014). Financial Market Supervision Report 2013. Praha: Czech National Bank.

Cornet, M. M., McNutt, J. J., Strahan, P. E., \& Tehranian, H. (2012). Liquidity risk management and credit supply in the financial crisis. Journal of Financial Economics, 101(2), 297-312. doi:10.1016/j.jfineco.2011.03.001.

Diamond, D., \& Dybvig, P. (1983). Bank runs, deposit insurance, and liquidity. Journal of Political Economy, 91(3), 401-419. doi:10.1086/261155.

Diamond, W. D., \& Rajan, R. G. (2001). Liquidity Risk, Liquidity Creation and Financial Fragility: A theory of banking [NBER Working paper no. 7430]. doi:10.3386/w7430.

Dinger, V. (2009). Do foreign-owned banks affect banking system liquidity risk? Journal of Comparative Economics, 37(4), 647-657. doi:10.1016/j.jce.2009.04.003.

Distinguin, I., Roulet, C., \& Tarazi, A. (2013). Bank regulatory capital and liquidity: Evidence from US and European publicly traded banks. Journal of Banking and Finance, 37(9), 32953317. doi:10.1016/j.jbankfin.2013.04.027.

Fielding, D., \& Shortland, A. (2005). Political Violence and Excess Liquidity in Egypt. Journal of Development Studies, 41(4), 542-557. doi:10.1080/00220380500092580.

Frait, J., \& Komárková, Z. (2011). Financial Stability, Systemic Risk and Macroprudential policy. In Financial Stability Report 2010/2011 (pp. 96-111). Praha: Czech National Bank.

Freixas, X., \& Rochet, J. C. (1997). Microeconomics of Banking. Massachusetts: Massachusetts Institute of Technology.

Gorton, G., \& Winton, A. (2000). Liquidity Provision, Bank Capital, and the Macroeconomy. [Working Paper of the University of Minnesota].

Grant, J. (2012). Liquidity Buffers of Australian-Owned ADIs. JASSA, 2012(3), 31-36.

HFSA. (2009). Annual report 2008. Budapest: Hungarian Financial Supervisory Authority.

Jurča, P., \& Rychtárik, Š. (2006). Stress Testing of the Slovak Banking Sector. BIATEC, 14(4), 15-21.

Kapadia, S., Drehmann, M., Elliot, J., \& Sterne, G. (2012). Liquidity risk, cash-flow constraints and systemic feedbacks [Bank of England Working Paper no. 456]. doi:10.2139/ ssrn.2093439.

Komárková, Z., Geršl, A., \& Komárek, L. (2011). Models for Stress Testing Czech Banks' Liquidity Risk [Working Paper Series of Czech National Bank no. 11].

Lei, A. C. H., \& Song, Z. (2013). Liquidity creation and bank capital structure in China. Global Financial Journal, 24(3), 188-202. doi:10.1016/j.gfj.2013.10.004. 
Lucchetta, M. (2007). What Do Data Say About Monetary Policy, Bank Liquidity and Bank Risk Taking? Economic Notes by Banca Monte dei Paschi di Siena SpA, 36(2), 189-203. doi:10.1111/j.1468-0300.2007.00180.x.

Memmel, C., \& Sachs, A. (2013). Contagion in the interbank market and its determinants. Journal of Financial Stability, 9(1), 46-54. doi:10.1016/j.jfs.2013.01.001.

Moore, W. (2010). How do financial crises affect commercial bank liquidity? Evidence from Latin America and the Caribbean [MPRA Paper no. 2010-21473].

Munteanu, I. (2012). Bank liquidity and its determinants in Romania. Procedia Economics and Finance, 2012(3), 993-998. doi:10.1016/s2212-5671(12)00263-8.

NBS. (2010). Analysis of the Slovak Financial Sector for the Year 2009. Bratislava: National Bank of Slovakia.

Negrila, A. (2010). The Role of Stress-test Scenarios in Risk Management Activities and in the Avoidance of a New Crisis. Theoretical and Applied Economics, 17(2), 5-24.

PFSA. (2008). Report on the condition of Polish banks in 2007. Warsaw: Polish Financial Supervision Authority.

PFSA. (2009). Report on the condition of Polish banks in 2008. Warsaw: Polish Financial Supervision Authority.

Rauch, C., Steffen, S., Hackethal, A., \& Tyrell, M. (2010). Determinants of Bank Liquidity Creation [Working Paper of Centre for Economic and International Studies]. doi:10.2139/ssrn.1343595.
Reinhart, C. M., \& Rogoff, K. (2009). The Aftermath of Financial Crises. American Economic Review, 99(2), 466-472. doi:10.1257/aer.99.2.466.

Rychtárik, Š. (2009). Liquidity Scenario Analysis in the Luxembourg Banking Sector [BCDL Working Paper no. 41].

Van den End, J. W. (2008). Liquidity StressTester: A macro model for stress-testing banks' liquidity risk [DNB Working Paper no. 175].

Vodová, P. (2013). Liquid assets in banking: What matters in the Visegrad Countries? E\&M Ekonomie a Management, 16(3), 113-129.

Vodová, P. (2015). To Lend or to Borrow on the Interbank Market: What Matters for Commercial Banks in the Visegrad Countries. Prague Economic Papers, 24(6), 662-677. doi:10.18267/j.pep.529.

Wells, S. (2004). Financial interlinkages in the United Kingdom's interbank market and the risk of contagion [Bank of England Working Paper no. 230]. doi:10.2139/ssrn.641288.

doc. Ing. Pavla Klepková Vodová, Ph.D. Silesian University in Opava School of Business Administration in Karviná Department of Finance and Accounting klepkova@opf.slu.cz

prof. Ing. Daniel Stavárek, Ph.D. Silesian University in Opava School of Business Administration in Karviná Department of Finance and Accounting stavarek@opf.slu.cz 


\title{
Abstract
}

\section{FACTORS AFFECTING SENSITIVITY OF COMMERCIAL BANKS TO BANK RUN INTHE VISEGRAD COUNTRIES}

\author{
Pavla Klepková Vodová, Daniel Stavárek
}

While managing liquidity, each bank should be prepared also for unexpected and exceptional events, such as bank runs. The aim of this paper is therefore to determine the maximum volume of deposits that can be withdrawn from individual banks operating in the Visegrad countries and to identify the determinants of their sensitivity to a bank run. The data cover the period from 2000 to 2014. Although bank liquidity, measured by the liquid asset ratio, decreased in all countries during the analyzed period, the level of liquidity differs among countries. We have simulated a bank run as a sudden withdrawal of $20 \%$ of client deposits. The ability of individual banks to survive this crisis scenario significantly differs. Nevertheless, as Czech and Hungarian banks were more liquid, they are better prepared for a potential bank run than Polish and Slovak banks. After that, using the panel data regression analysis, we tested seven bank-specific factors and seven macroeconomic factors. The sensitivity of commercial banks from the Visegrad countries to a possible bank run is determined mainly by different aspects of bank liquidity (not only the level of bank liquidity, but also connection to bank lending activity, the way of its financing and also activity on the interbank market). Among the other bank specific factors, profitability, capital adequacy and size of the banks are relevant in some countries. When it comes to macroeconomic factors, interest rate and unemployment rate are important. However, we can conclude that the most important factor is the level of bank liquidity: banks with a sufficient buffer of liquid assets are safer than other banks, particular during periods of financial distress.

Key Words: Bank run, liquid asset ratio, scenario analysis, panel data regression analysis.

JEL Classification: C23, G01, G21.

DOI: 10.15240/tul/001/2017-3-011 